\title{
Constraints faced by tribal women in adoption of improved aonla cultivation and post harvest practices
}

\author{
VANDANA VISHWAKARMA* AND SNEHLATA MAHESHWARI \\ Department of Home Science Extension and Communication Management, College of Home Science, \\ Maharana Pratap University of Agriculture and Technology, UDAIPUR (RAJASTHAN) INDIA
}

\begin{abstract}
Aonla fruit is highly nutritive with great medicinal benefits. It is a wonderful fruit and one of the precious gifts of nature to man. The purpose of this study was to determine the constraints being faced by tribal women in adoption of improved aonla cultivation and post harvest practices. The present study was carried out in Udaipur district of Rajasthan. Total ten villages were selected from three clusters viz., Ogna, Jhadol and Baghpura. A sample of 200 tribal women was selected through random sampling technique from selected villages with proportion to the size of sample in the selected villages. Selected respondents were interviewed personally using well structured pre tested interview schedule. The collected data were analyzed by using appropriate statistical tool to infer results. The finding of the study indicates that economic and storage and marketing constraints perceived as major constraints by the respondents.
\end{abstract}

KEY WorDS : Tribal women, Aonla cultivation, Post harvest practices

View Point Article : Vishwakarma, Vandana and Maheshwari, Snehlata (2017). Constraints faced by tribal women in adoption of improved aonla cultivation and post harvest practices. Internat. J. Home Sci. Extn. \& Comm. Manage., 4 (1): 30-34. DOI : 10.15740/HAS/IJHSECM/4.1/30-34.

Article History : Received : 21.10.2016; Revised : 24.11.2016; Accepted : 11.12.2016

* Author for correspondence (E-mail : vandana27.sln@gmail.com) 